\title{
Akuntabilitas Pengelolaan Alokasi Dana Desa Di Desa Ledokombo Kecamatan Ledokombo Kabupaten Jember Tahun 2015
}

\section{(Accountability Management Of Funds Allocated Villages In Rural Village Ledokombo District Ledokombo Jember 2015)}

\author{
Alwan Sri Kustono, Putri Purnamasari dan Djoko Supatmoko \\ Jurusan Akuntasi, Fakultas Ekonomi, Universitas Jember (UNEJ) \\ Jln. Kalimantan 37, Jember 68121 \\ E-mail: alwan.sri@gmail.com
}

\begin{abstract}
Abstrak
Penerapan otonomi bagi desa akan menjadi kekuatan bagi pemerintah desa untuk mengurus, mengatur dan menyelenggarakan rumah tangganya sendiri berdasarkan prinsip tranparansi (keterbukaan) dan akuntabilitas (pertanggungjawaban). Pertanggungjawaban tersebut meliputi perencanaan, pelaksanaan, penatausahaan, pelaporan dan pertanggungjawaban. Setiap tahapan proses pengelolaan tersebut memiliki aturan-aturan yang harus dipahami dan dilaksanakan sesuai batasan waktu yang telah ditetapkan. Namun ada permasalahan baru ketika pertanggungjawaban desa yang dituntut untuk dikelola secara transparan, akuntabel dan partisipatif, tidak diimbangi dengan kesiapan pemerintah desa dan masyarakat dalam melaksanakan proses tersebut. Ketidaksiapan tersebut disebabkan keterbatasan kemampuan dan kualitas sumber daya manusia dalam mengelola Alokasi Dana Desa. Penelitian ini dilakukan secara analisa deskriptif dengan pendekatan kualitatif untuk mengetahui pertanggungjawaban dalam pengelolaan Alokasi Dana Desa di Desa Ledokombo, dan faktor-faktor yang dapat menghambat dan mendukung proses pengelolaan tersebut. Selain itu, pengumpulan data menggunakan teknik trianggulasi dengan metode wawancara, observasi dan dokumentasi. Hasil penelitian ini menunjukkan bahwa tahap perencanaan, pelaksanaan, pelaporan, dan pertanggungjawaban sudah dilaksanakan dengan baik walaupun ada beberapa prosedur yang belum atau tidak tepat waktu dalam pelaksaannya seperti Surat Pertanggung Jawaban dibuat dan disampaikan melebihi batas waktu yang telah ditetapkan.
\end{abstract}

Kata Kunci: Akuntabilitas, Alokasi Dana Desa, Pengelolaan Keuangan Desa.

\begin{abstract}
The autonomy implementation for the village will be the village government is power to administer, regulate and to conduct their own household based on the principle of transparency (openness) and accountability (responsibility). The accountability includes planning, action, administration, reporting and responsibility. Each stage of the management process has rules that must be understood and implemented in a settled period of time. But there are new problems when the village accountability is required to be managed in a transparent, accountable and participatory way, the execution somehow does not coincide with the village functionaries and dwellers' preparedness in implementing the process. The unpreparedness is caused by the limited capacity and quality of the human resources in managing the Village Fund Allocation. This study was conducted by using descriptive analysis along with qualitative approach to determine the accountability in the management of the Village Fund Allocation in Ledokombo village, and the factors that can inhibit and support the management process. In addition, the data collection method that was applied was triangulation technique with interview, observation and documentation. The results of this study showed that the planning, implementation, reporting, and accountability had been implemented well although there were still some procedures that had not been apt in terms of time allocation in the implementation process such as some issues in writing accountability documents and overdue delivering system.
\end{abstract}

Keywords: Accountability, Village Fund Allocation, Financial Management village.

\section{Pendahuluan}

Berdasarkan Undang-Undang Republik Indonesia Nomor 6 Tahun 2014 Tentang Desa, desa adalah kesatuan masyarakat hukum yang memiliki batas wilayah yang berwenang untuk mengatur dan mengurus urusan pemerintahan, kepentingan masyarakat setempat berdasarkan prakarsa masyarakat, hak asal usul, dan atau hak tradisional yang diakui dan dihormati dalam sistem pemerintahan Negara Kesatuan Republik Indonesia. Pembangunan desa menjadi sangat penting karena secara langsung bersentuhan dengan masyarakat yang menjadi permasalahan utama dalam pembangunan pemerintahan. Desa mempunyai peran dan wewenang untuk mengurus, mengelola dan mengatur penyelenggaraan pemerintahan, pembangunan, pembinaan kemasyarakatan, dan pemberdayaan desa..
Otonomi tersebut diberikan oleh pemerintah pusat kepada daerah dengan tujuan digunakan secara luas, nyata dan bertanggung jawab, berdasarkan prinsip transparansi (keterbukaan) dan akuntabilitas (bertanggung jawab). Diharapkan dengan konsep ini dapat menumbuhkan prakarsa dan kreativitas masyarakat serta dapat mendorong peningkatan partisipasi masyarakat dalam pembangunan dengan memanfaatkan sumber daya dan potensi yang tersedia. Implementasi otonomi bagi desa akan menjadi kekuatan bagi pemerintah desa untuk mengurus, mengatur dan menyelenggarakan rumah tangganya sendiri, sekaligus bertambah pula beban tanggung jawab dan kewajiban desa, namun demikian penyelenggaraan pemerintahan tersebut tetap harus dipertanggungjawabkan. 
Pertanggungjawaban yang dimaksud diantaranya adalah pertanggungjawaban dalam pengelolaan anggaran desa. Siklus pengelolaan keuangan desa diatur dalam Peraturan Pemerintah Nomor 47 Tahun 2015 Pasal 93 menyebutkan bahwa pengelolaan keuangan desa terdiri dari beberapa tahapan meliputi perencanaan, pelaksanaan, penatausahaan, pelaporan, dan pertanggungjawaban. Setiap tahapan proses pengelolaan memiliki aturan-aturan yang harus dipahami dan dilaksanakan sesuai batasan waktu yang telah ditetapkan. Pengelolaan keuangan desa diatur dalam Permendagri Nomor 113 Tahun 2014 Pasal 2 yang memuat asas pengelolaan keuangan harus mengandung unsur tranparan, akuntabel, partipatif, yang dilakukan secara disiplin anggaran.

Salah satu unsur yang dikelola dalam keuangan desa yaitu pendapatan asli desa diklasifikasikan menjadi tiga yaitu Pendapatan Asli Desa (PADesa), transfer, dan pendapatan lain-lain. Pendapatan Asli Desa terdiri dari hasil usaha, hasil asset, swadaya atau partisipasi dan gotong royong, dan lainlain Pendapatan Asli Desa seperti hasil pungutan desa. Pendapatan Transfer terdiri dari Dana Desa, bagian dari Hasil Pajak Daerah Kabupaten/Kota dan Retribusi Daerah, Alokasi Dana Desa, Bantuan Keuangan dari APBD Provinsi dan Kabupaten/Kota. Sedangkan untuk pendapatan lain-lain berupa hibah dan sumbangan dari pihak ketiga yang tidak mengikat berupa pemberian uang, hasil kerjasama atau bantuan perusahaan yang berlokasi di desa.

Pedoman Alokasi Dana Desa yang tertuang dalam Peraturan Pemerintah Nomor 47 Tahun 2015, Alokasi Dana Desa merupakan dana perimbangan yang diterima kabupaten/kota dalam Anggaran Pendapatan dan Belanja Daerah kabupaten/kota setelah dikurangi Dana Alokasi Khusus. Alokasi Dana Desa diberikan kepada desa berdasarkan perhitungan Alokasi Dana Desa Merata dan Alokasi Dana Desa Proporsional.

Dari beberapa Kabupaten yang berada di Provinsi Jawa Timur, Kabupaten Jember merupakan salah satu daerah otonom yang telah melaksanakan prinsip-prinsip otonomi daerah dengan berusaha mengoptimalkan potensi-potensi desa demi terselenggaranya pemerintahan yang bersih. Namun masih ada saja pihak-pihak yang menyalahgunakan dana yang telah diberikan. Pertengahan tahun 2015 telah tercatat dua kasus korupsi yang melibatkan aparat pemerintah desa terkait dengan penyalahgunaan Alokasi Dana Desa. Mengutip pernyataan Kepala Bagian Pemerintahan Desa Kabupaten Jember, Winardi yang dimuat dalam situs surabaya.bisnis.com Minggu, 30/11/2014 18:23 WIB, dua kepala desa tersebut yaitu desa Paseban kecamatan Kencong, dan Desa Pecoro Kecamatan Rambipuji. Untuk itu diperlukan adanya peningkatan kinerja aparatur Pemerintah Desa dan peran dari masyarakat untuk ikut mengawasi penggunaan anggaran yang telah dialokasikan oleh Pemerintah Pusat.

Kecamatan Ledokombo menjadi salah satu kecamatan dengan jumlah Alokasi Dana Desa terbesar di Kabupaten Jember yaitu Rp 7.914.839.532. Kecamatan Ledokombo terdiri dari 10 Desa yaitu Desa Ledokombo, Desa Sumber Lesung, Desa Sumber Salak, Desa Suren, Desa Sumber Bulus, Desa Sukogidri, Desa Karang Paiton, Desa Slateng, Desa Sumber Anget, dan Desa Lembengan. Pembagian Alokasi Dana Desa di wilayah Kecamatan Ledokombo sebagai berikut:
Tabel 1. Pembagian Alokasi Dana Desa di Wilayah Kecamatan Ledokombo Tahun 2015

\begin{tabular}{|c|c|c|}
\hline Desa & $\begin{array}{c}\text { Jumlah ADD } \\
\text { Merata }\end{array}$ & $\begin{array}{c}\text { Jumlah ADD } \\
\text { Proposional }\end{array}$ \\
\hline Suren & Rp 694,247,902 & Rp 125,232,662 \\
\hline Sumber Salak & Rp 694,247,902 & Rp 209,187,674 \\
\hline Sumber Bulus & Rp 694,247,902 & Rp $135,581,717$ \\
\hline Sumber Lesung & Rp 694,247,902 & $\mathrm{Rp} 79,140,030$ \\
\hline Lembengan & Rp 694,247,902 & Rp 102,292,789 \\
\hline Sumber Anget & Rp 694,247,902 & Rp 36,547,151 \\
\hline Ledokombo & Rp 694,247,902 & $\mathrm{Rp} 46,305,112$ \\
\hline Slateng & Rp 694,247,902 & Rp 148,758,752 \\
\hline Sukogidri & Rp 694,247,902 & Rp 50,329,452 \\
\hline Karang Paiton & Rp 694,247,902 & Rp 38,985,173 \\
\hline Total & Rp 6,942,479,020 & Rp 972,360,512 \\
\hline
\end{tabular}

Sumber: Bagian Pemerintahan Desa, 2015 (diolah)

Penelitian ini dilakukan di Desa Ledokombo yang secara administratif terletak di wilayah Kecamatan Ledokombo Kabupaten Jember dengan luas wilayah kurang lebih 656,5 Ha. Desa Ledokombo terdiri dari 3 (tiga) Dusun yaitu Dusun Krajan, Dusun Sumbernangka dan Dusun Pasar dengan jumlah penduduk sekitar 4.334 jiwa. Sebagian besar penduduk Desa Ledokombo bermatapencaharian sebagai petani, peternak dan buruh pabrik. Desa Ledokombo termasuk wilayah ideal dengan jumlah penduduk kurang lebih 647 orang per $\mathrm{km}^{2}$. Suatu wilayah dikatakan ideal apabila jumlah penduduk diwilayah tersebut kurang dari 1000 jiwa per $\mathrm{km}^{2}$. Sehingga hal tersebut dapat menunjang pembangunan secara optimal agar teciptanya masyarakat sejahtera. Untuk itu peneliti melakukan penelitian di Desa Ledokombo dengan fokus terhadap sistem pengelolaan Alokasi Dana Desa dalam proses pembangunan sarana dan prasarana untuk pemberdayaan masyarakat.

Berdasarkan latar belakang masalah tersebut, peneliti ingin mengetahui akuntabilitas khusunya dalam hal perencanaan, pelaksanaan, pengawasan, serta pertanggungjawaban Alokasi Dana Desa di Desa Ledokombo, Kecamatan Ledokombo, kabupaten Jember Tahun 2015. Penelitian ini dimaksudkan untuk mengetahui pengelolaan dan pemanfaatan Alokasi Dana Desa dalam menunjang pembangunan di Desa Ledokombo yang bertujuan untuk pemberdayaan masyarakat.

\section{Metode}

\section{Rancangan Penelitian}

Penelitian ini adalah penelitian deskriptif dengan pendekatan kualitatif. Menurut Bogdan dan Taylor (L.J. Maleong, 2011:4) metode penelitian kualitatif merupakan prosedur penelitian yang menghasilkan data deskriptif berupa katakata tertulis atau lisan dari orang-orang dan perilaku yang dapat diamati. Menurut Nawawi (dalam Soejono dan Abdurrahman, 1999:24) jenis penelitian deskriptif merupakan langkah-langkah melakukan representasi objektif tentang gejala pada masalah yang diselidiki. Metode ini menitik 
beratkan pada observasi dan suasana ilmiah. Ditambahkan oleh Husaini dan Purnomo (2009:130) bahwa penelitian deskriptif kualitatif adalah menguraikan pendapat responden apa adanya sesuai dengan pertanyaan penelitian, kemudian dianalisis dengan kata-kata yang melatarbelakangi responden berperilaku seperti itu, direduksi, ditriangulasi, disimpulkan, dan diverifikasi.

\section{Jenis Dan Sumber Data}

Sumber data dalam penelitian ini didapatkan dengan dua cara yaitu data primer dan data sekunder. Data primer adalah data yang diperoleh langsung dari sumbernya dengan cara observasi dan interview atau wawancara terstruktur. Data sekunder adalah data yang diperoleh dari pihak ketiga atau literature, dokumentasi, tulisan-tulisan, sebagai pembanding dari data yang diperoleh yaitu buku-buku referensi, UndangUndang, dan media elektronik.

\section{Informan Penelitian}

Penentuan informan dalam penelitin ini adalah orang yang terlibat langsung dalam mengelola Alokasi Dana Desa, yaitu tim pelaksana desa atau Tim Pengelola Kegiatan (TPK) yang terdiri dari Kepala desa sebagai penanggungjawab, PTPKD (Pelaksana Teknis Pengelolaan Keuangan Desa) yang terdiri dari sekretaris desa, bendahara, dan anggota BPD (Badan Permuyawaratan Desa). Selain itu, Bagian Pemerintahan Desa Kabupaten Jember yang memiliki wewenang melakukan koordinasi dengan Tim Koordinator Kabupaten mengenai pengeleloaan keuangan desa di Kabupaten Jember.

\section{Pengujian Keabsahan Data Dengan Teknik Triangulasi}

Definisi triangulasi adalah teknik pemeriksaan keabsahan data yang memanfaatkan sesuatu yang lain dalam membandingkan hasil wawancara terhadap objek penelitian (Moloeng, 2010:330). Apabila peneliti menggunakan teknik trianggulasi, maka sebenarnya peneliti mengumpulkan data sekaligus menguji kredibilitas data. Triangulasi dapat dilakukan dengan menggunakan teknik yang berbeda (Nasution, 2003:115) yaitu wawancara, observasi dan dokumen. Triangulasi ini selain digunakan untuk mengecek kebenaran data juga dilakukan untuk memperkaya data. Menurut Nasution (2003), selain itu triangulasi juga dapat berguna untuk menyelidiki validitas tafsiran peneliti terhadap data, karena itu triangulasi bersifat reflektif.

\section{Hasil dan Pembahasan}

\section{Hasil}

Penelitian ini dilakukan di Desa Ledokombo, Kecamatan Ledokombo, Kabupaten Jember. Desa Ledokombo terletak di sentral Kecamatan Ledokombo yang penduduknya sebagian besar mempunyai mata pencaharian sebagai petani atau buruh tani. Secara Geografis Desa Ledokombo memiliki curah hujan mencapai 15,89 mm berdasarkan data BPS Kabupaten Jember Tahun 2010 sehingga tanah di Desa Ledokombo termasuk dalam kategori subur yang cocok digunakan sebagai lahan pertanian.

\section{Pembahasan}

\section{Akuntabilitas Sistem Pengelolaan Alokasi Dana Desa di Desa Ledokombo}

Akuntabilitas Alokasi Dana Desa di Desa Ledokombo diwujudkan dalam lima tahap, tahapan tersebut meliputi tahap perencanaan, pelaksanaan, penatausahaan, pelaporan, dan pertanggungjawaban sebagaimana dalam ketentuan Peraturan Bupati Nomor 13 Tahun 2015 mengenai Pedoman Pengelolaan Alokasi Dana Desa Di Kabupaten Jember Tahun 2015. Pertanggungjawaban Alokasi Dana Desa ini terintegrasi dengan pertanggungjawaban APBDes.

\section{Tahap Perencanaan Alokasi Dana Desa}

Alokasi Dana Desa (ADD) menjadi salah satu sumber pendapatan yang dikelola desa dan penggunaannya terintegrasi dengan Anggaran Pendapatan dan Belanja Desa (APBDes). Tahap Perencanaan ADD merupakan tahap awal dalam perencanaan penggunaan dana ADD. Perencanaan ADD perlu dilakukan agar penggunaannya dapat berjalan efektif, efisien, ekonomis dan tepat sasaran sehingga pembangunan dapat berjalan secara optimal. Perencanaan ADD dimulai dengan Musyawarah Dusun yang dilakukan disetiap dusun yaitu Dusun Sumber Nangka, Dusun Pasar dan Dusun Krajan. Musyawarah Dusun ini melibatkan unsur Pemerintah Desa, BPD, LPMD, PKK, RT/TW dan beberapa warga yang berada di dusun tersebut. Musyawarah Dusun dilakukan untuk mengetahui aspirasi masyarakat dan kebutuhan masyarakat disetiap dusunnya serta menentukan prioritas untuk melakukan pembangunan.

Partisipasi masyarakat dalam pembangunan desa dapat dilakukan dengan cara memberikan masukan, usulan, kritik dan saran terhadap pembangunan desa. Selain itu, diharapkan masyarakat dapat berperan aktif dalam berbagai forum musyawarah desa seperti Musrembangdes. Tingkat partisipasi masyarakat dalam kegiatan Musrembangdes Desa Ledokombo cukup tinggi. Tingkat kehadiran masyarakat Desa Ledokombo ditunjukkan dalam daftar hadir yang tertera pada Tabel 2.

Tabel 2. Tingkat Kehadiran Masyarakat dalam Musrembangdes 2015

\begin{tabular}{lccc}
\hline Jabatan & Undangan & Kehadiran & Presentase \\
\hline Kepala Desa & 1 orang & 1 orang & $1 \%$ \\
Perangkat Desa & 11 orang & 11 orang & $11 \%$ \\
BPD & 9 orang & 8 orang & $8 \%$ \\
LPMD & 5 orang & 4 orang & $4 \%$ \\
PKK & 5 orang & 2 orang & $2 \%$ \\
RT/RW & 25 orang & 25 orang & $25.00 \%$ \\
Bidang Kesehatan & 5 orang & 5 orang & $5 \%$ \\
Bidang & & & \\
Pendidikan & 9 orang & 8 orang & $8 \%$ \\
Warga & 30 orang & 30 orang & $30 \%$ \\
JUMLAH & 100 orang & 94 orang & $94 \%$ \\
\hline
\end{tabular}

Sumber: Laporan Hasil Musrembangdes Deesa Ledokombo Tahun 2015 (diolah)

Dari data tersebut dapat diketahui bahwa tingkat kehadiran masyarakat Desa Ledokombo sangat tinggi. Hal tersebut menandakan adanya kesadaran masyarakat untuk ikut serta dalam proses pembangunan demi kemajuan Desa Ledokombo. Dengan besarnya antusias masyarakat dalam 
proses pembangunan dapat berdapat positif terhadap kinerja Pemerintah Desa dalam menyusun rencana pembangunan yang benar-benar sesuai dengan kebutuhan masyarakat.

Selain peran dari masyarakat, diperlukan pula kinerja Pemerintah Desa yang baik dalam pengelolaan dan pemanfaatan dana tersebut. Seperti dalam menyusun peraturan desa berdasarkan hasil Musrembangdes untuk membuat Rencana Peraturan Desa dan RPJMDes. RPJMDes memuat Rencana Kerja Pembangunan Desa dan dituangkan dalam rancangan APBDesa tahun berkenaan dan dicatat dalam pendapatan dan belanja desa. APBDesa yang telah disetujui oleh Kepala Desa dan ketua Badan Permusyawaratan Desa disampaikan kepada bupati melalui camat untuk diverifikasi. Apabila dalam tahap verifikasi ditemukan adanya kekurangan, maka Tim Fasilitator Kecamatan akan mengembalikan APBDes kepada desa untuk segera dilengkapi dan proses pencairan dapat segera dilaksanakan.

Alokasi Dana Desa pada prinsipnya digunakan untuk biaya operasional perangkat desa dan pemberdayaan masyarakat. Operasional pemerintah desa terdiri dari penghasilan tetap Kepala Desa dan perangkat desa, tunjangan BPD, Insentif RT/RW, operasional LPMD, Operasional Karang Taruna, Operasional TP-PKK, dan lain-lain. Untuk besarnya penghasilan tetap Kepala desa dan perangkat desa telah ditetapkan oleh Bupati Jember melalui Peraturan Bupati Nomor 13 Tahun 2013, sehingga Penghasilan Tetap Kepala Desa dan Perangkat Desa di wilayah Kabupaten Jember besarnya sama. Hal ini dilakukan dengan tujuan agar tidak ada kecemburuan social antar desa di wilayah Kabupaten Jember. Sedangkan pemberdayaan masyarakat terdiri dari pembangunan fisik, honor tim pelaksana, dan sebagainya. Berdasarkan Laporan Rencana Penggunaan ADD Desa Ledokombo, Kecamatan Ledokombo Tahun 2015 secara terperinci digunakan untuk kegiatan sebagai berikut:

Tabel 3. Rencana Penggunaan Dana Alokasi Dana Desa (ADD) Tahun 2015

\begin{tabular}{|c|c|c|c|}
\hline Uraian & $\begin{array}{c}\text { Pagu } \\
\text { Anggaran }\end{array}$ & $\begin{array}{c}\text { Tahap I } \\
50 \%\end{array}$ & $\begin{array}{c}\text { Tahap II } \\
50 \%\end{array}$ \\
\hline $\begin{array}{l}\text { Penghasilan Tetap } \\
\text { Kepala Desa dan } \\
\text { Perangkat Desa } \\
\text { Lainnya }\end{array}$ & 210.000 .000 & 140.000 .000 & 70.000 .000 \\
\hline Tunjangan BPD & 57.300 .000 & 38.800 .000 & 23.500 .000 \\
\hline Insentif RT/RW & 58.800 .000 & 39.200 .000 & 19.600 .000 \\
\hline $\begin{array}{l}\text { Operasional } \\
\text { LPMD }\end{array}$ & 5.000 .000 & 5.000 .000 & - \\
\hline $\begin{array}{l}\text { Operasional } \\
\text { Karang Taruna }\end{array}$ & - & - & - \\
\hline $\begin{array}{l}\text { Operasional TP- } \\
\text { PKK }\end{array}$ & 12.000 .000 & 8.000 .000 & 4.000 .000 \\
\hline $\begin{array}{l}\text { Operasional } \\
\text { Pemerintah Desa }\end{array}$ & 54.606 .226 & 6.175 .000 & 48.431 .226 \\
\hline Operasional BPD & 3.100 .000 & 3.100 .000 & - \\
\hline $\begin{array}{l}\text { Operasional } \\
\text { RT/RW }\end{array}$ & 1.255 .000 & 1.225 .000 & - \\
\hline
\end{tabular}

\begin{tabular}{lcc}
\hline $\begin{array}{l}\text { Pemberdayaan } \\
\text { Masyarakat }\end{array}$ & 2.000 .000 & - \\
\hline $\begin{array}{l}\text { Belanja Modal/ } \\
\text { Aset Tetap }\end{array}$ & 57.750 .000 & -57.750 .000 \\
\hline $\begin{array}{l}\text { Belanja Modal/ } \\
\text { Bangunan }\end{array}$ & 278.771 .788 & -278.771 .788 \\
\hline Jumlah & 740.553 .014236 .500 .000 & 504.053 .014 \\
\hline
\end{tabular}

Sumber: Laporan Rencana Penggunaan Dana ADD Desa Ledokombo Tahun 2015

Laporan perencanaan disusun berdasarkan hasil Musrembangdes yang disesuaikan dengan besarnya ADD yang dihitung berdasarkan ADD Merata dan ADD proposianal. Selain itu, perencanaan tersebut disesuaikan dengan peraturan yang telah ditentukan oleh Pemerintah Kabupaten Jember seperti pada besarnya penghasilan tetap Kepala Desa dan perangkatnya. Laporan perencanaan ini kemudian disahkan dengan Peraturan Desa yang menjadi dasar penyelenggaraan pemerintahan desa dalam proses pembangunan desa dalam waktu satu tahun. Diharapkan dengan prosedur-prosedur tersebut, proses perencanaan ADD dapat berjalan secara transparan dan akuntabel kepada masyarakat dengan mengikutsertakan masyarakat dalam forum musyawarah dan menginformasikan hasil perencanaan tersebut kepada masyarakat sehingga dapat mencerminkan akuntabilitas dalam proses perencanaan ADD.

\section{Tahap Pelaksanaan Alokasi Dana Desa}

Pada tahap Pelaksanaan ADD diawali dengan proses pencairan ADD dengan mengajukan permohonan pencairan kepada Camat yang dilampiri dengan Surat Permohonan Pencairan dan Rencana Penggunaan Dana. Kemudian Camat merekomendasikan permohonan pencairan kepada Bank yang akan menyalurkan langsung Rekening Kas Pemerintah Desa. Pencairan dana Tunjangan BPD, Insentif RT/RW, Operasional TP PKK Desa, Operasional LKD lainnya dan Operasional Pemerintahan Desa serta pemberdayaan fisik/infrastruktur direalisasikan tunai oleh Kepala Desa dan Bendahara Desa.

Tahap pelaksanaan dilakukan oleh Tim Pengelola Kegiatan (TPK) yang diketuai oleh ketua LPMD dan Kepala Desa sebagai penanggungjawab. Pelaksanaan ADD disesuaikan dengan kondisi lokal dan potensi yang dimiliki oleh masingmasing desa. Pada saat pembangunan, TPK memiliki kewajiban untuk menginformasikan secara transparan kepada masyarakat mengenai proses pembangunan dengan memasang papan informasi di lokasi kegiatan tersebut. Papan informasi tersebut berisi beberapa hal yang terkait dengan proses pembangunan tersebut seperti tanggal dimulai kegiatan, sumber dana, kontraktor yang melakukan pembangunan, dan prosentase penyelesaian. Selain itu, TPK juga berkewajiban melakukan dokumentasi dan melaporkan proses pembangunan mulai dari awal atau $0 \%$, setengah jadi atau $50 \%$ sampai bangunan tersebut terselesaikan $100 \%$.

\section{Tahap Pertanggungjawaban Alokasi Dana Desa}

Pertanggungjawaban Alokasi Dana Desa terintegrasi dengan pertanggungjawaban APBDes. Dalam pertanggungjawaban ADD, Kepala Desa memiliki peran sebagai penanggungjawab dalam Tim Pengelola Kegiatan. 
Pertanggungjawaban tersebut mencakup semua tahapan pengelolaan ADD, mulai dari tahap perencanaan, pelaksanaan, sampai tahap pengawasan. Setiap kegiatan yang dilakukan dalam pengelolaan ADD dicatat dan dibuktikan secara sistematis dalam bentuk laporan. Laporan tersebut terdiri dari laporan berkala dan laporan akhir. Menurut Peraturan Bupati Nomor 13 Tahun 2015, laporan berkala menjadi tugas bendahara desa yang dilakukan setiap bulannya paling lambat tanggal 10 bulan berikutnya. Bendahara desa wajib mempertanggungjawabkan uang melalui laporan pertanggungjawaban kepada Kepala Desa. Untuk laporan akhir berisi laporan penggunaan ADD yang mencakup perkembangan pelaksanaan, penyerapan dana dan penyelesaiaan akhir penggunaan dana. Laporan akhir ini dilaporkan paling lambat tanggal 31 Desember tahun berkenaan dan disampaikan kepada Bupati.

\section{Pelaporan}

Pelaporan dilakukan untuk mengetahui kagiatan apa saja yang dilakukan dalam pengelolaan Alokasi Dana Desa, mulai dari tahap perencanaan, pelaksanaan dan pengawasannya. Pelaporan juga dilakukan sebagai bentuk pertanggungjawaban Pemerintah Desa kepada masyarakat dan kepada pemerintah atasnya secara tranparan. Selain itu, pelaporan digunakan sebagai bahan evaluasi apakah pengelolaan keuangan desa telah berjalan secara efektif, efisien dan ekonomis, serta untuk mengetahui proses pelaksanaan ADD sudah berjalan sesuai dengan peraturan yang berlaku.

Terdapat dua bentuk pelaporan, yaitu laporan secara berkala dan laporan akhir. Laporan secara berkala dilakukan oleh bendahara desa kepada kepala desa yang dilakukan setiap bulannya paling lambat tanggal 10 bulan berikutnya. Laporan tersebut mencakup laporan penerimaan dana dan penggunaan dana. Sedangkan laporan akhir dilakukan pada akhir tahun anggaran dan paling lambat dilaporkan tanggal 31 Desember tahun berkenaan dan disampaikan kepada bupati dalam hal ini yaitu Kepala Bagian Pemerintah Desa sekretariat Kabupaten melalui camat. Bentuk laporan akhir yaitu Laporan Pertanggungjawaban Realisasi Dana dan Surat Pertanggungjawaban (SPJ). Laporan pertanggungjawaban bendahara kepada Kepala Desa tidak dapat dilakukan apabila belum ada dana yang masuk ke rekening kas desa.

Desa dapat mengajukan permohonan penyaluran ADD setelah ada sosialisasi Peraturan Bupati dari Pemerintah Kabupaten Jember. Sosialisasi tersebut mengenai Bantuan Keuangan Desa yang berkaitan dengan jumlah dana yang akan diterima oleh masing-masing desa baik dana yang berasal dari Alokasi Dana Desa. Dana Desa, maupun Bagi Hasil Pajak dan Retribusi Daerah.

Pelaporan Alokasi Dana Desa pada tahap perencanaan dengan menggunakan Laporan Rencana Anggaran Biaya dan Laporan Rencana Penggunaan Dana yang nantinya dijadikan syarat untuk mengajukan permohonan penyaluran dana ADD kepada Bupati. ADD dicairkan kepada setiap desa dalam dua tahap yaitu tahap pertama sebesar 50\% dan tahap kedua 50\%. Pada tahap kedua, untuk pencairan dana ADD harus menyertakan SPJ tahap pertama. Hal ini dilakukan sebagai bentuk pertanggungjawaban pemerintah desa kepada pemerintah diatasnya seperti kecamatan dan kabupaten, dan bertujuan untuk mempermudah pengawasan pengelolaan
ADD. SPJ pada setiap tahapan dilaporkan dan dicetak sebanyak 3 kali yang nantinya diserahkan kepada pihak kecamatan dalam hal ini Tim Fasilitator Kecamatan dan kepada pemerintah kabupaten sebagai Tim Koordinator Kabupaten.

\section{Pengawasan Dan Evaluasi Pengelolaan Alokasi Dana Desa}

Pengawasan dalam pengelolaan Alokasi Dana Desa dilakukan oleh aparat pemerintah mulai dari tingkat kabupaten, tingkat kecamatan dan tingkat desa bersama masyarakat. Pengawasan secara fungsional dilakukan oleh Inspektorat Kabupaten, pengawasan secara teknis dilakukan oleh Tim Koordinasi Kabupaten dan Tim Fasilitator Kecamatan, dan pengawasan secara operasional oleh BPD dan MasyarakatEvaluasi dilakukan untuk mengetahui hal-hal apa saja yang perlu untuk diperbaiki dan hambatan atau kendala yang dihadapi oleh aparat pemerintah terutama pemerintah desa dalam pengelolaan ADD.

Di tingkat kabupaten, pengawasan dan evaluasi dilakukan oleh Tim Koordinator Kabupaten yang terdiri dari Bupati sebagai pengarah, Sekretaris Kabupaten sebagai penanggungjawab, Ketua Asisten Pemerintahan Setkab, Wakil Ketua Kepala Bagian Pemerintahan Desa Setkan dan Sekretaris Kepala Sub Bagian Pendapatan dan Kekayaan Desa di Bagian Pemeritahan Desa dengan anggota yang terdiri dari Bappekab, Inspektur Kab, Kepala Dinas Pendapatan Kab, Kepala Dinas PU Cipta Karya Kab, Kepala Dinas PU Bina Marga Kab, Kepala Badan Pemberdayaan Masyarakat Kab, Kepala Dinas Kesehatan Kab, Ketua TP PKK Kab, Kepala Badan Pengelolaan Keuangan dan Aset Kab, Kepala Bagian Pembangunan Setkab, Kepala Bagian Hukum Setkab dan kepala Bagian Pemerintahan Desa Setkab.

Pengawasan di tingkat Kecamatan dilakukan oleh Tim Fasilitator Kecamatan yang terdiri dari Camat dan Kepala Seksi Kecamatan sebagai pengawas administratif yang bertugas memverifikasi kelengakapan dokumen administrasi, dan unsur UPT Dinas PU Bina Marga Kecamatan selaku pengawasan teknis atau pengawasan kegiatan fisik. Pengawasan pada tingkat desa dilakukan oleh BPD bersama masyarakat.

\section{Faktor Penghambat Dan Pendukung Pengelolaan Alokasi Dana Desa}

Pengelolaan Alokasi Dana Desa dalam setiap tahapannya mulai dari perencanaan, pelaksanaan sampai dengan pertanggungjawaban masih mengalami beberapa kendala dalam pelaksanaannya. Tetapi kendala tersebut harus bisa diminimalkan agar pelaksanaan pengelolaan ADD dapat berjalan lancar, tepat waktu dan tepat sasaran. Selain itu, pelaksanaan tersebut harus dapat mencerminkan prinsip transparansi, akuntabel, tertib serta disiplin.

Salah satu faktor yang dapat menghambat proses pelaksanaan ADD yaitu kualitas SDM (sumber daya manusia) yang kurang memadai khususnya pihak pengelola pelaksanaan ADD tidak dapat tepat waktu pengumpulan SPJ (Surat Pertanggungjawaban) maupun LPJ (Laporan Pertanggungjawaban). Untuk ADD, SPJ dibuat sebanyak dua kali yaitu SPJ Pelaksanaan ADD Tahap I dan SPJ Pelaksanaan ADD Tahap II. SPJ Pelaksanaan ADD Tahap I 
menjadi syarat permohonan penyaluran ADD Tahap II. Hal ini dilakukan sebagai bentuk pertanggungjawaban dan pengawasan pelaksanaan ADD sehingga apabila terdapat masalah atau kendala dapat segera diatasi.

Apabila SPJ Tahap I tidak dapat selesai tepat waktu maka permohonan penyaluran dan pencairan ADD Tahap II tertunda. Akibatnya, pencairan ADD tertunda maka kegiatankegiatan yag didanai dengan ADD tidak dapat dilaksanakan dan sudah pasti proses pembangunan juga tidak berjalan lancar. Penyampaian SPJ tepat waktu atau tidak tergantung dari Tim Pengelola Kegiatan yang membuat laporan tersebut.

Laporan Pertanggungjawaban disampaikan kepada Bupati melalui camat paling lambat Bulan Januari tahun berikutnya. Laporan Pertanggungjawaban nantinya akan digunakan sebagai bahan evaluasi oleh Tim Koordinasi Kabupaten mengenai pengelolaan kuangan desa. Apabila terdapat kendala ataupun permasalahan dapat dicari solusinya dan dapat segera teratasi. Selain itu, hasil evaluasi ini menentukan peraturan yang dibuat sebelumnya masih dapat digunakan, atau perlu perbaikan dan tambahan. Hal ini bertujuan untuk mempermudah pemerintah desa dalam mengelola keuangan desa. Setelah dilakukan evaluasi dan penetapan peraturan, Pemerintah Kabupaten akan mengadakan sosialisasi Perbup pada tahun yang berkenaan.

\section{Simpulan}

Berdasarkan hasil analisis penelitian dan pembahasan yang peneliti lakukan di Desa Ledokombo, Kecamatan Ledokombo, Kabupaten Jember Tahun 2015 dapat disimpulkan bahwa pada tahap perencanaan dalam pengelolaan Alokasi Dana Desa di Desa Ledokombo Kecamatan Ledokombo Kabupaten Jember telah berlangsung dengan baik sesuai dengan peraturan yang berlaku. Tahap perencanaan dimulai dengan dilakukannya Musrembangdes (Musyawarah Rencana Pembangunan Desa) yang dihadiri oleh pemerintah desa, BPD (Badan Permusyawaratan Desa), LPMD (Lembaga Pemberdayaan Masyarakat Desa), dan tokoh masyarakat. Hal ini dilakukan dengan tujuan menampung aspirasi masyarakat dan mengetahui apa saja yang dibutuhkan oleh masyarakat dan yang menjadi prioritas dalam pembangunan.

Pada tahap pelaksanaan dalam pengelolaan Alokasi Dana Desa di Desa Ledokombo diawali dengan pengajuan permohonan penyaluran ADD dan tahap pencairan. Pada tahap ini dilakukan oleh TPK (Tim Pengelola Kegiatan) yang berkewajiban untuk menginformasikan secara transparan kepada masyarakat mengenai proses pembangunan. Untuk mendukung hal tersebut, digunakan papan informasi di lokasi kegiatan yang berisi sumber dana, tanggal pengerjaan dan lain sebagainya yang berkenaan dengan kegiatan tersebut. TPK juga berkewajiban melakukan dokumentasi melakukan dokumentasi dan melaporkan proses pembangunan mulai $0 \%$, $50 \%$ dan $100 \%$.

Pada tahap pelaporan dalam pengelolaan Alokasi Dana Desa di Desa Ledokombo sudah berjalan dengan baik walaupun ada beberapa prosedur yang belu atau tidak tepat waktu dalam pelaksanaannya. Terdapat dua bentuk pelaporan yaitu laporan berkala dibuat oleh bendahara yang nantinya dipertanggungjawabkan kepada kepala desa setiap bulannya dan laporan akhir disampaikan kepada bupati paling lambat
31 Desember tahun berkenaan. Selama ini apabila ada keterlambatan pencairan ADD, bendahara tidak dapat membuat laporan berkala karena tidak ada kegiatan yang dilaksanakan. Selain itu, kepala desa juga menyampaikan laporan realisasi pelaksanaan APBDes kepada bupati berupa laporan semester pertama dan laporan semester akhir.

Dan pada tahap pertanggungjawaban dalam pengelolaan Alokasi Dana Desa di desa Ledokombo sudah berjalan dengan baik walaupun masih ada beberapa prosedur yang belum atau tidak tepat waktu dalam pelaksanaannya. Prosedur tersebut yaitu SPJ dibuat dan disampaikan tidak tepat waktu, dan penyusunan laporan berkala setiap bulan yang dilakukan oleh bendahara belum atau tidak tepat waktu. Walaupun terdapat prosedur yang belum atau tidak tepat waktu, prosedur yang lain seperti penyusunan laporan akhir dari penggunaan ADD sudah dilaporkan atau dibuat sesuai dengan peraturan perundang-undangan.

\section{Referensi}

Arifiyanto, Febri. 2014. Akuntabilitas Pengelolaan Alokasi Dana Desa Di Kecamatan Umbulsari Kabupaten Jember Tahun 2012. Jurnal Ilmiah. Universitas Jember: Jember.

Dadang, Solihin. 2007. Penerapan Good Governance Di Sektor Publik Untuk Meningkatkan Akuntabilitas Kinerja Lembaga Publik. (Online). Tersedia: http://www.slideshare.net/DadangSolihin/penerapan-goodgovernancedi-sektor-publik-untuk-meningkatkan-akuntabilitas-kinerjalembaga-publik. (14 Maret 2016)

Haryanto. 2007. Akuntansi Sektor Publik. Semarang: Badan Penerbit Universitas Diponegoro.

Kurniawan, Teguh. 2006. "Perbaikan Pelayanan Publik di Era Otonomi Daerah Antara Harapan dan Kenyataan", dalam Aliansi Vol.27, No.XXXI, Januari

Lalolo krina, Loina. 2003. Indikator Alat Ukur Prinsip Akuntabilitas, Transparansi dan Partisipasi. Jakarta: Badan Perencanaan PembangunanNasional.

Lembaga Administrasi Negara dan Badan Pengawasan Keuangan dan Pembangunan RI 2000, Akuntabilitas dan Good Governance, Modul 15, Modul Sosialisasi Sistem Akuntabilitas Kinerja Instansi Pemerintah (AKIP), LAN BPKP RI, Jakarta.

Mardiasmo. 2002. Otonomi Daerah dan Manajemen Keuangan Daerah. Andi: Yogyakarta.

Moleong, Lexy. J. (2010). Metodologi Penelitian Kualitatif. rev. ed. Bandung: PT. Remaja Rosdakarya.

Nana Syaodih Sukmadinata. (2007). Metode Penelitian Tindakan. Bandung: Remaja Rosda Karya

Nasution. 2003. Metode Research, Jakarta: PT. Bumi Aksara.

Nawawi, Hadari. 1999.Metode Penelitian Bidang Sosial. Gajah Mada University Press: Yogyakarta.

Nordiawan, Deddi, Iswahyudi SP dan Maulidah Rahmawati. 2007. Akuntansi Pemerintahan, Salemba Empat: Jakarta.

Peraturan Pemerintah Nomor 47 Tahun 2015

Peraturan Bupati Nomor 13 Tahun 2015 Tentang Pedoman Pengelolaan Alokasi Dana Desa

Peraturan Menteri Dalam Negeri Nomor 113 Tahun 2014 Tentang Pedoman Pengelolaan Keuangan Desa

Peraturan Menteri Dalam Negeri Nomor 114 Tahun 2014 Tentang Pedoman Pembangunan Desa

Rosalinda, Okta. 2014 Pengelolaan Alokasi Dana Desa (ADD) Dalam Menunjang Pembangunan Desa. (Studi Kasus: Desa Segodorejo dan Desa Ploso Kerep, Kecamatan Sumobito, Kabupaten Jombang. Jurnal Ilmiah. Universitas Brawijaya: Malang. 
Salim, Peter dan Yenny Salim, Kamus Besar Bahasa Indonesia Kontemporer, Modern English Press, Jakarta, 1991.

Simbolon, Anthon. 2006. Akuntabilitas Birokrasi Publik. Edisi Revisi. Yogyakarta: UGM

Soleh, Chabib dan Heru Rochansjah. 2015. Pengelolaan Keuangan Desa. Fokusmedia: Bandung.

Sugiyono. 2010. Metode Penelitian Kuantitatif Kualitatif dan R\&D Alfabeta: Bandung.
Sulistiyani, Ambar Teguh, 2004. Kemitraan Dan Model-Model Pemberdayaan. Gava Media: Yogyakarta

Undang-Undang Republik Indonesia Nomor 6 Tahun 2014 Tentang Desa

Undang-Undang Republik Indonesia Nomor 32 tahun 2004

Usman, Husaini dan Purnomo Setiady Akbar. 2009. Metodologi Penelitian Sosial. Jakarta: Bumi Aksara. 